\title{
Sustainable Development of Oil and Gas Potential of the Arctic and Its Shelf Zone: The Role of Innovations
}

\author{
Diana Dmitrieva * (D) and Natalia Romasheva \\ Organization and Management Department, Saint-Petersburg Mining University, \\ Saint-Petersburg 199106, Russia; natasmir84@mail.ru \\ * Correspondence: diana-dmitrieva@mail.ru; Tel.: +7-921-302-4523
}

Received: 12 November 2020; Accepted: 7 December 2020; Published: 8 December 2020

check for updates

\begin{abstract}
Currently, the Russian oil and gas industry is characterized by significant reserves depletion and the late stage of development of most fields. At the same time, new fields that are brought into industrial development, in the majority of cases, have hard-to-recover reserves. Furthermore, most prospective oil and gas deposits are located in the Arctic and its offshore territories and their development is much more complicated due to regional peculiarities. This substantiates the necessity of a special approach to the development of the oil and gas potential of the Arctic, based on innovation. The goal of the paper is to reveal the role of innovation activity in the sustainable development of the oil and gas potential in the Arctic and its offshore zone. The paper briefly presents the main urgent factors of Arctic development, which highlight the necessity of innovation for its sustainability. Then, it introduces the methods used for the research: the Innovation Policy Road mapping (IPRM) method in accordance with Sustainable Development Goals (SDGs) concept for clarifying how innovations will lead to sustainable development. In terms of results, this paper presents an innovation policy roadmap for the sustainable development of oil and gas resources of the Russian Arctic and its shelf zone and identifies the role of innovation within this development.
\end{abstract}

Keywords: innovations; sustainable development; hydrocarbon resources; Arctic; oil and gas potential; offshore oil and gas fields

\section{Introduction}

The Russian Arctic is a unique region with significant resources, great potential and strategic importance for Russia due to its unique mineral resource base (especially oil and gas deposits), promising ways to develop logistics infrastructure, and other factors. About $12 \%$ of Russia's territory is located beyond the Arctic Circle [1] and about $12-15 \%$ of the country's gross domestic product is created in the Arctic zone and it provides about a quarter of exports [2]. Provided the intensive and effective development of this region, especially the offshore zone, development of which requires a special approach with innovation technologies and proper skills, Russia can increase its resource potential several times, which will lead to an increase in the competitiveness of the Russian economy at the global level.

The accelerating climate change and altering accessibility to valuable minerals has affected expectations for a growing supply of northern resources globally. Plans for Arctic resource extraction are often considered as a vehicle for local economic development, which is reflected in the development strategies issued in Russia, Greenland, Canadian Nunavut, or Alaska [1].

The distribution of undiscovered hydrocarbon reserves between Arctic countries is presented in Figure 1 [2]. 


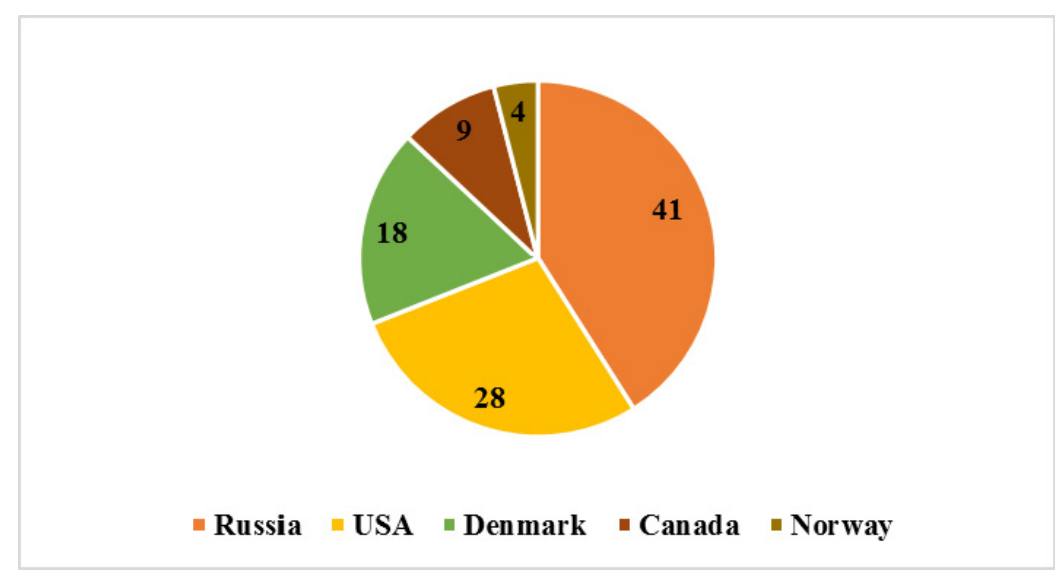

Figure 1. Distribution of undiscovered oil reserves between the Arctic countries, $\%$.

The oil and gas complex of the Russian Federation is a large-scale unit of the national economy and the most important sphere of its resource-innovative development. A quarter of Russia's oil and gas condensate reserves and more than $70 \%$ of gas reserves (their cost is more than $\$ 20$ trillion [3]) are concentrated in the Arctic zone of Russia and about $83 \%$ of gas and $12 \%$ of oil is produced there; however, its raw material potential is not fully developed. The largest oil and gas basins in the Arctic are the East Barents, South Kara, Laptev, East Siberian and Chukotka. Russia is developing Arctic hydrocarbon deposits on the Kola Peninsula, in Norilsk, in the northern regions of Western Siberia. The Nenets Autonomous district is an important center of oil production, while Yamal has become a center of gas production.

Twenty six oil and gas fields have been discovered on the Arctic shelf, seven of which are ready for development [4]. The deposits are located in the waters of three seas: the Barents, Pechora and Kara seas with total recoverable reserves of oil of about 0.6 billion tons, gas -8.5 trillion cubic meters [4].

The production of hydrocarbons is expected to grow in the near future. The planned volumes of production for Prirazlomnoye field-about 5 million tons (up to 2025). It is expected that production will start at the Dolginsky field (up to 2030) and at 1-2 more offshore fields. Besides at least 10 operating license areas for the development of hydrocarbons are located in the Pechora Sea (total recoverable resources are about 600 million tons of oil and 161 billion cubic meters of gas). At the same time, most of the license areas contain mainly oil deposits [5].

However, development of these resources is characterized by a number of obstacles, the main of which are the following [4]: high cost of exploration work, especially drilling exploration wells (several hundred million dollars at sea depths more than $1000 \mathrm{~m}$ ); lack of a technologically simple alternative to traditional well drilling methods; and ineffectiveness of existing systems for collecting, preparing and transporting extracted products, etc.

Development of such oil and gas potential characterized by hard-to-recover hydrocarbons at great depths, shelf seas and the Arctic ocean, exploitation of oil deposits in the later stages of development, and the transportation of oil and gas across large distances through pipelines require developed infrastructure, qualified personnel and significant innovation potential. However, innovative development of the region is affected by such negative factors as the following [2]: undeveloped infrastructure of the Arctic zone (transport, information and telecommunication, market, etc.); low profitability of mining operations caused by the absence of developed infrastructure and developed power energy systems; the declarative character of laws and regulations and weak control over the implementation of the state strategies and programs; and imbalance in economic and innovative development between the separate Arctic territories and regions, etc.

A number of challenges of innovative development of the Arctic zone are connected with the absence of a systematic approach to the innovation infrastructure [6]. 
Despite that, the natural environment of the Arctic, including its shelf, is characterized by increased terms of restoration of the eco-balance due to man-made impacts. The main climatic characteristics of the region that complicate development of oil and gas potential in the Arctic zone are the following [4]: oil transportation in difficult natural and climatic conditions; difficult meteorological, temperature and hydrological conditions; difficult ice situation; extremely difficult wind regime; difficult bottom topography; high water depth in the presence of ice loads; ice period about 7-8 months, etc.

It should also be noted that Russian oil and gas companies are coming out of the period of low cost of oil production. The cost of production at new fields is 2-3 times higher than in traditional territories [7]. The Russian oil and gas industry is currently not sufficiently innovative in technological development and management [7], while the world's leading oil and gas companies invest in the development of high-tech technologies for the development of oil and gas deposits, which makes it possible to justify cost-effective ways to develop hard-to-recover hydrocarbon reserves. Therefore, innovations in the oil and gas industry also promote rational use of mineral resources, ensure the sustainable development of the region and increase the company's revenues.

The development of the Arctic zone of Russia is a priority task for the coming decades according to national policy [8,9]. The main national interests and the main directions of implementation of the state policy of the Russian Federation in the Arctic are presented in Table 1.

Table 1. National priorities in Russian Arctic development.

\begin{tabular}{|c|c|c|}
\hline & $\begin{array}{l}\text { The Main National Interests } \\
\text { of the Russian Federation in the Arctic }\end{array}$ & $\begin{array}{l}\text { The Main Directions of Implementation } \\
\text { of the State Policy of the Russian Federation in the Arctic }\end{array}$ \\
\hline (b) & $\begin{array}{l}\text { Ensuring the sovereignty and territorial } \\
\text { integrity of the Russian Federation; } \\
\text { Preserving the Arctic as a territory of peace, } \\
\text { stability and mutually beneficial partnership; } \\
\text { Ensuring a high quality of life and well-being of } \\
\text { the population of the Arctic zone of the } \\
\text { Russian Federation; } \\
\text { Development of the Arctic zone of the Russian } \\
\text { Federation as a strategic resource base and its } \\
\text { rational use in order to accelerate the economic } \\
\text { growth of the Russian Federation; } \\
\text { Development of the Northern sea route as a } \\
\text { competitive national transport communication } \\
\text { zone of the Russian Federation on the } \\
\text { world market; } \\
\text { Environmental protection in the Arctic, } \\
\text { protection of the native habitat and traditional } \\
\text { way of life of indigenous small-numbered } \\
\text { peoples living on the territory of the Arctic zone } \\
\text { of the Russian Federation. }\end{array}$ & $\begin{array}{l}\text { (a) Social and economic development of the Arctic zone } \\
\text { of the Russian Federation, as well as development of } \\
\text { its infrastructure; } \\
\text { (b) Development of science and technology for the } \\
\text { development of the Arctic; } \\
\text { (c) Environmental protection and environmental safety; } \\
\text { (d) Development of international cooperation; } \\
\text { (e) Ensuring the protection of the population and } \\
\text { territories of the Arctic zone of the Russian } \\
\text { (f) Eederation from natural and man-made emergencies; } \\
\text { (g) Eussian Federation; } \\
\text { (h) Pussian Federation; } \\
\text { (h) Protection of the state border of the } \\
\text { Russian Federation. }\end{array}$ \\
\hline
\end{tabular}

It is expected that the strategy for the development of the Russian Arctic zone until 2035 will be approved soon. According to the draft of this document prepared by the Ministry of Eastern Development of Russia, by 2030 the share of oil produced in the Arctic should reach $22 \%$ of the total oil production in Russia, and by $2035-25 \%$ [9].

As it is observed from national interests and the situation in the oil and gas industry, the sustainable development of oil and gas potential in the Arctic and its shelf is a very urgent research and industrial issue. One of the most important aspects of the Arctic zone's sustainable development is an environmental issue. The importance of ecological as well as social aspects for sustainable development of the Arctic region cannot be overestimated [6,10]. Innovative development of the region in an ecological aspect will help to save ecosystems of the important strategic region of the Russian Federation for the further effective and sustainable development of the country [6]. 
In order to achieve these goals, it is necessary to develop a new approach to innovation activity in the Arctic zone for sustainable development of its resources. This paper aimed at defining the role of innovation in the sustainable development of oil and gas potential in the Russian Arctic and at the creation of an innovation policy roadmap for this purpose.

According to the purpose of this paper, we conducted an academic literature review of the following aspects: we track the connection between sustainability and innovation in the academic literature, study the role of innovation in the sustainable development of resources, study the innovation process in resource based industries, and study the concept of Sustainable Development Goals (SDGs), perspectives and problems of the Arctic and the necessity of an innovation approach, as well as the methodology of producing an innovation policy roadmap.

Many studies show the critical connection between innovation and sustainability. Innovation and sustainability create a critical link in the achievement of environmental, economic and social development [11-13]. Technological innovations are considered as an important element for sustainable development [11] and are recognized as a key factor of success for the development of society and the long-term survival of companies [14]. Some authors suppose that technological innovation causes the economic, environmental and social dimensions of sustainable development only for high income countries [15]. However, at the same time a very urgent issue remains-how to create innovations and remain economically profitable, ecologically sustainable and socially responsible [14].

Some studies underline the importance of innovation for sustainable development and the achievement of SDGs [16,17]. The Sustainable Development Goals (SDGs) are a collection of 17 interrelated goals, the achievement of which represents sustainable development [18]. They cover all aspects of sustainable development [19] and were introduced in order to understand sustainability in a more detailed and universally acceptable way [20]. Furthermore, private companies are the main factor in providing their achievement [20]. In this context, SDGs direct companies towards operating in sustainable way. At the same time, a very urgent issue appears-how to connect global SDGs with local goals [21] and how to correlate them with companies' goals. Therefore, there are studies that investigate the contribution of different industries in SDGs' achievement [22,23]. For the purpose of our research, we paid more attention to contribution of mining in SDGs. The report "Mapping Mining to the Sustainable Development Goals: An Atlas" presents the interpretation of the concept of SDGs for the mining sector [23]. It represents how certain mining corporate practices on a global scale contribute to certain SDGs. Some authors suppose that such an approach will push the mining industry towards integrating its practices "within a broader sustainable development framework" [24].

\subsection{Role of Innovations in Sustainable Development of Resources}

Innovation plays a key role in addressing mining challenges $[25,26]$. Mineral resources are key to the development of society [27]. Mineral resource depletion and the complication of extraction conditions substantiates the importance of new technologies and the energy revolution for the further availability of resources. In addition to economic considerations, it is essential to reconcile mining activity with environmental protection and to allay the concerns of local populations [27]. Some researchers suppose that sustainability implies the equal presence of economic, social and environmental sustainability [28]. Furthermore, in order to attain environmental sustainability, consumption of the world's natural resources, such as materials, energy fuels, land, water, etc., needs to be at a sustainable rate. In order to achieve economic sustainability, businesses and countries need to use their resources efficiently and responsibly. Social sustainability comes when any social system achieves good social well-being [28].

At the same time, there is a question in the research community-is the use of non-renewable resources sustainable? It depends critically on information that is unavailable to contemporary observers [29,30]. It could, however, be available soon due to future technological innovations.

In the context of the innovative development of the regional mineral complex, it is necessary to pay attention to the existing mining, oil and gas companies and to intensify the attracting of investments, the upgrading of equipment, the attracting of highly qualified personnel, etc. [6]. Some authors pay 
attention to innovations in the oil and gas industry [31] and suggest that an open innovation model can facilitate the process of responding to specific industry threats (for example, environmental and social pressure) $[32,33]$ as well as study barriers that interrupt the innovation process in the oil industry [34].

\subsection{Problems of Arctic Development}

Much literature covers the perspectives and problems of the Arctic and the necessity of an innovation approach. Most all of them underline the importance of innovations for Arctic development as well as emphasize the necessity of environmental and social aspects in Arctic development [35-39]. It is substantiated that Russia obtains great resources and influence in the Arctic, but at the same time the Russian economy is not efficient enough and its commitment to sustainability (especially in Arctic development) might become more significant [35]. Despite the fact that hydrocarbon resources exploration employs millions of people and plays an important role in the Russian economy, it is also potentially harmful and often leads to negative environmental and social consequences [35].

Hydrocarbon exploration of offshore areas is difficult due to harsh weather conditions, darkness, ice, icing, and large distances [37]. In many Arctic regions, the existing infrastructure is insufficient to permit an adequate response to pollution of hydrocarbon exploitation. Special environmental and ecological conditions demand innovation technologies and protocols [37]. The lack of infrastructure along the Arctic coastlines is also considered as a very big problem in the case of reaching the coastline by oil spill, as many locations cannot be reached by cleaning equipment from land [37].

Despite the considerable attractiveness of offshore projects, its implementation is accompanied by difficulties such as the harsh weather conditions, the difficult geology (sea oil and gas production), as well as a lack of necessary technologies and infrastructure, making these projects time consuming and capital intensive [38]. Some studies concern factors and conditions that influence hydrocarbon production in the Arctic [39], while others concentrated on risks that appear during offshore oil and gas field exploitation [40]. It is established that there is a disproportionally high risk for Arctic ecosystems and various species, ecosystems, and communities are adversely affected (including indigenous peoples) [40]. In addition, problems of low population density and underdevelopment of transport infrastructure and features of different Arctic regions are discussed in the literature [1].

The issue of Arctic shelf sustainable development is also discussed and it is revealed that an economic and socioecological approach to Arctic shelf sustainable development is the only acceptable approach [41]. It is suggested that sustainable development of the Arctic shelf should be directed to the creation of the centers for economic development (CED) (oil and gas business clusters) [41].

\subsection{Innovation Policy Roadmap}

As it was mentioned, the main problem of innovative Arctic development is an absence of systemicity. Some authors suggest that system failures are result of "a lack of linkage and fragmentation between innovation actors" [42]. In order to regularize and organize actors, processes and challenges, a process of policy design is recommended [43]. In this context, the Innovation Policy Roadmap (IPRM) is suggested for systematizing innovation processes by consolidating drivers of innovations, policies, need for sectoral development as well as key enablers [42].

As for implementation of the IPRM as an instrument of policy-making for the Arctic, Hintsala et al. suggest the general strategic roadmap for Finland in the context of developing Arctic competences [36], but it does not consider issue of sustainable development of oil and gas potential.

Thus, analysis of previous studies revealed that there is no literature devoted to investigation of the contribution of innovation in the Arctic zone in SDGs' achievement as well as providing an innovation policy roadmap for the sustainable development of the oil and gas potential of the Russian Arctic zone (including the shelf zone). This paper is going to fill this gap and contribute to the innovation literature and literature concerning sustainable development of oil and gas resources by resolving two key issues: tracking the role and contribution of innovations in sustainable development in the context 
of achieving SDGs and the usage of the IPRM as an instrument for identification of the main aspects of sustainable development or Russian Arctic oil and gas potential.

\section{Materials and Methods}

In order to reveal the role of innovations, we use IPRM in accordance with SDGs for clarifying how innovations will lead to sustainable development.

IPRM method suggests combining two frameworks-the systemic transformation roadmap and technology road mapping [43]. It integrates analysis of social, environmental, industrial and other aspects in policy practice that arise from technological development, as well as present actors involved in the process, and facilitates the creation of a common vision as the basis of innovation policy $[36,44]$. Different approaches suggest different elements [36,43,44]; the general framework of the IPRM is presented in Figure 2.

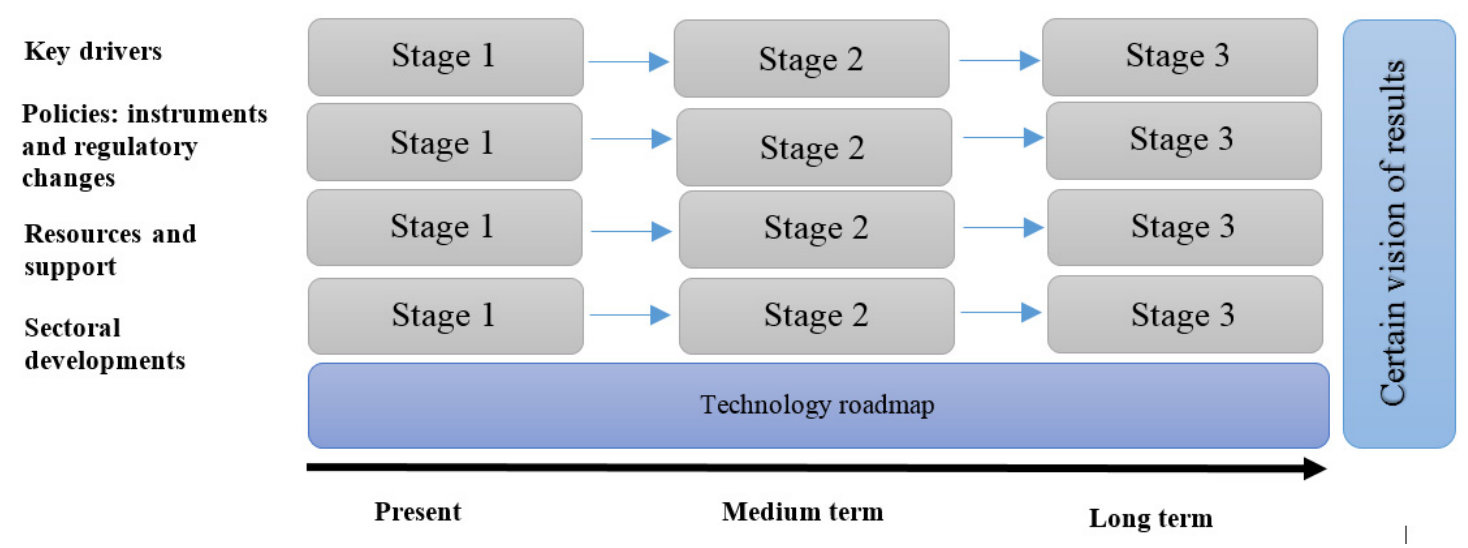

Figure 2. Framework for innovation policy roadmap creation.

The IPRM method shows how to achieve a certain vision that reflects the planned results. In order to reflect the results of sustainable development of oil and gas potential of the Arctic and the shelf zone, we adopt the concept of SDGs.

The concept of SDGs suggests the following goals—goal 1: No Poverty; goal 2: Zero Hunger; goal 3: Good Health and Well-being; goal 4: Quality Education; goal 5: Gender Equality; goal 6: Clean Water and Sanitation; goal 7: Affordable and Clean Energy; goal 8: Decent Work and Economic Growth; goal 9: Industry, Innovation and Infrastructure; goal 10: Reduced Inequality; goal 11: Sustainable Cities and Communities; goal 12: Responsible Consumption and Production; goal 13: Climate Action; goal 14: Life Below Water; goal 15: Life on Land; goal 16: Peace, Justice and Strong Institutions; goal 17: Partnerships to achieve the Goal [18].

The report "Mapping Mining to the Sustainable Development Goals: An Atlas" says that mining is a very urgent and global industry, which often located in distant, ecologically fragile and not developed areas that may include many indigenous lands and territories. It is totally concerned with the development of the oil and gas potential of the Arctic zone, especially its shelf territories. While mining is managed appropriately, it can create jobs, promote innovation and bring investment and infrastructure, even in changing environments, for a long-time. However, when managed poorly, mining can also lead to environmental degradation, displaced populations, inequality and increased conflict, among other challenges [23]. Mining activities have great impacts on land, water, climate, flora, fauna and people.

Atlas tracks the connection between mining and the SDGs by using examples of good practice in the industry and existing knowledge and resources in sustainable development that could make useful contributions to the SDGs in each sphere (Figure 3). 


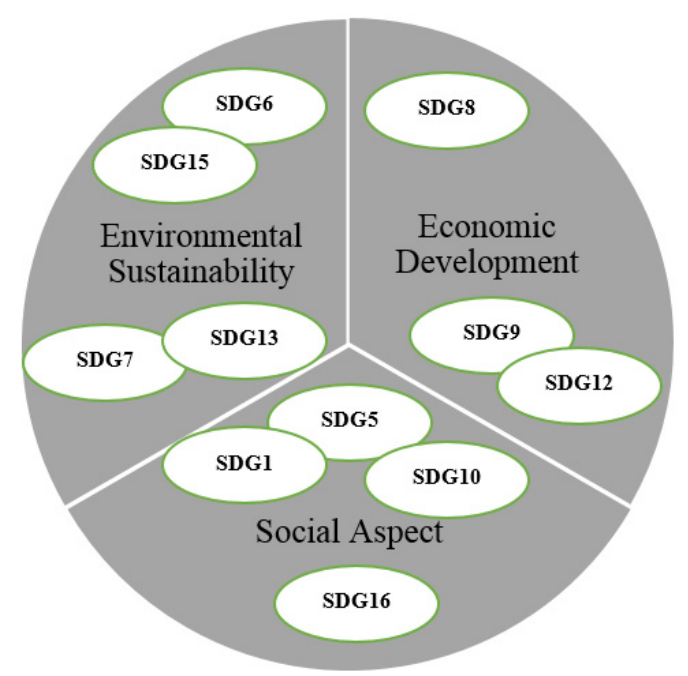

Figure 3. Sustainable development goals in mining according to [23].

Mining has a significant impact on local communities by bringing economic opportunities, as well as challenges relating to livelihoods and human rights. Mining generates significant revenues through taxes, royalties and dividends for governments to invest in economic and social development, in addition to opportunities for jobs and business locally [23]. As for economic development-mining has great impact on economic development and growth at the local, regional and even national levels.

\section{Results and Discussion}

We adopt a SDGs approach to Arctic conditions and oil and gas exploration on its territory and the territory of the Arctic shelf. We analyze and select SDGs that could be achieved by using innovations for development of oil and gas potential in the Arctic. This approach is a basis for revealing the role of innovations in SDGs' achievement and therefore in sustainable development of oil and gas potential of the Arctic and its shelf zone. We reveal enabling innovative technologies using the adopted SDGs' concept in order to track the contribution of innovations in sustainable development of oil and gas potential of the Russian Arctic zone (including the shelf zone).

Due to the threats that may appear during hydrocarbon production on the shelf (accidental oil spills; emergency emissions into the atmosphere; acceleration of global warming, ice melting, and extinction of rare animal species), significant attention should be paid to saving ecosystems under water. According to the features of oil and gas extraction on the shelf zone, SDG14-Life below water-is of particular importance. The hard climate, Arctic ice, lack of any coastal and road infrastructure, and difficulties in the development of the shelf area substantiate the necessity of an innovative approach for shelf development (advanced technologies, such as ice machines that are capable of fully producing oil and gas on the Arctic shelf are the means that can provide this).

The Arctic infrastructure in Russian part is quite poor and requires further development [45]. Moreover, local communities have legal or traditional rights, therefore exploration and exploitation within their territories requires taking into account their interests. The projects on developing of hydrocarbon resource deposit must be evaluated, taking into account the social potential of the project [45]. In such circumstances, SDG11-Sustainable Cities and Communities-is urgent for the achievement of sustainable development of oil and gas potential in the Arctic.

The arctic region (and especially its shelf zone) is characterized by very difficult working conditions. The state strategy for the development of the Arctic requires the attraction of human resources because the current situation indicates the outflow of population from the northern regions [46]. Companies need to engage qualified personnel by themselves due to hard climatic conditions, a shortage of key infrastructural elements in the Arctic region and imperfection of the legislative norms and government programs to support personnel. However, for the sustainable development of the oil and gas potential 
of the region, it is necessary to ensure the well-being of personnel as well as the native population. The development of oil and gas resources as well as future shipping routes (due to global warming, the northern Siberian route reduces the distance between major ports [47]) create one of the most serious problems for circumpolar indigenous peoples and their lands [48]. Significant harm to indigenous peoples is caused by industrial companies as they exploit natural resources, the locations of which often coincide with the areas used for the traditional lifestyles and economic activities of aboriginal peoples [49]. Therefore, SDG3 - Good Health and Well-being-needs to be included.

Despite that, the development of the Arctic region is impossible without cooperation at all levels and in all spheres. The more difficult the conditions for resources' exploration and extraction, the more scientific research and innovations are required [41]. The main goals of Russia in its Arctic policy are to utilize its natural resources, use the seas as a transportation infrastructure in Russia's interests, protect its ecosystems, and ensure that it remains a zone of peace and cooperation with other countries [6]. This is impossible without partnership and cooperation. Cooperation between states and subsoil users in the event of the discovery of a trans-boundary hydrocarbon deposit is extremely important [45]. The necessity of cooperation between oil and gas companies, interregional cooperation in the innovation sphere, and cooperation between research centers and private companies for the creation of adapted technologies [6] makes SDG17—Partnerships to achieve the Goal-very urgent for the sustainable development of oil and gas potential in the Arctic.

According to the specifics of oil and gas potential development as well as its influence on the region's development, we suppose that the following goals and their aspects should also be involved in our research (Figure 4).

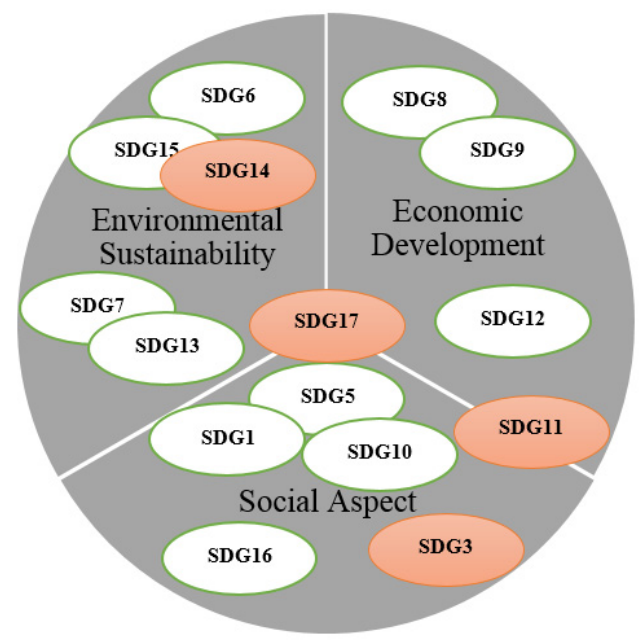

Figure 4. Sustainable development goals in the development of oil and gas potential of the Arctic and its shelf.

Using the IPRM method and the adopted SDGs concept, we created an innovation policy roadmap for the sustainable development of the Russian Arctic zone (Figure 5).

The roadmap consists of five elements. "Key drivers" are the global challenges that affect the development of oil and gas potential in the Arctic and support sustainable development goals related to this. The main global drivers are the increase in global energy demand, the depletion of traditional reserves, and climate change. As for drivers for Russia, the most significant is the strategic importance of the oil and gas industry for Russia as well as its national interests in the region. An increasing importance of environmental and social aspects also drives innovation activity for oil and gas potential development. The second element- "Policies: instruments and regulatory framework" — describes measures and changes that are needed to drive demand for innovative solutions, to provide economic incentives to industry, and to promote the implementation of innovations. 


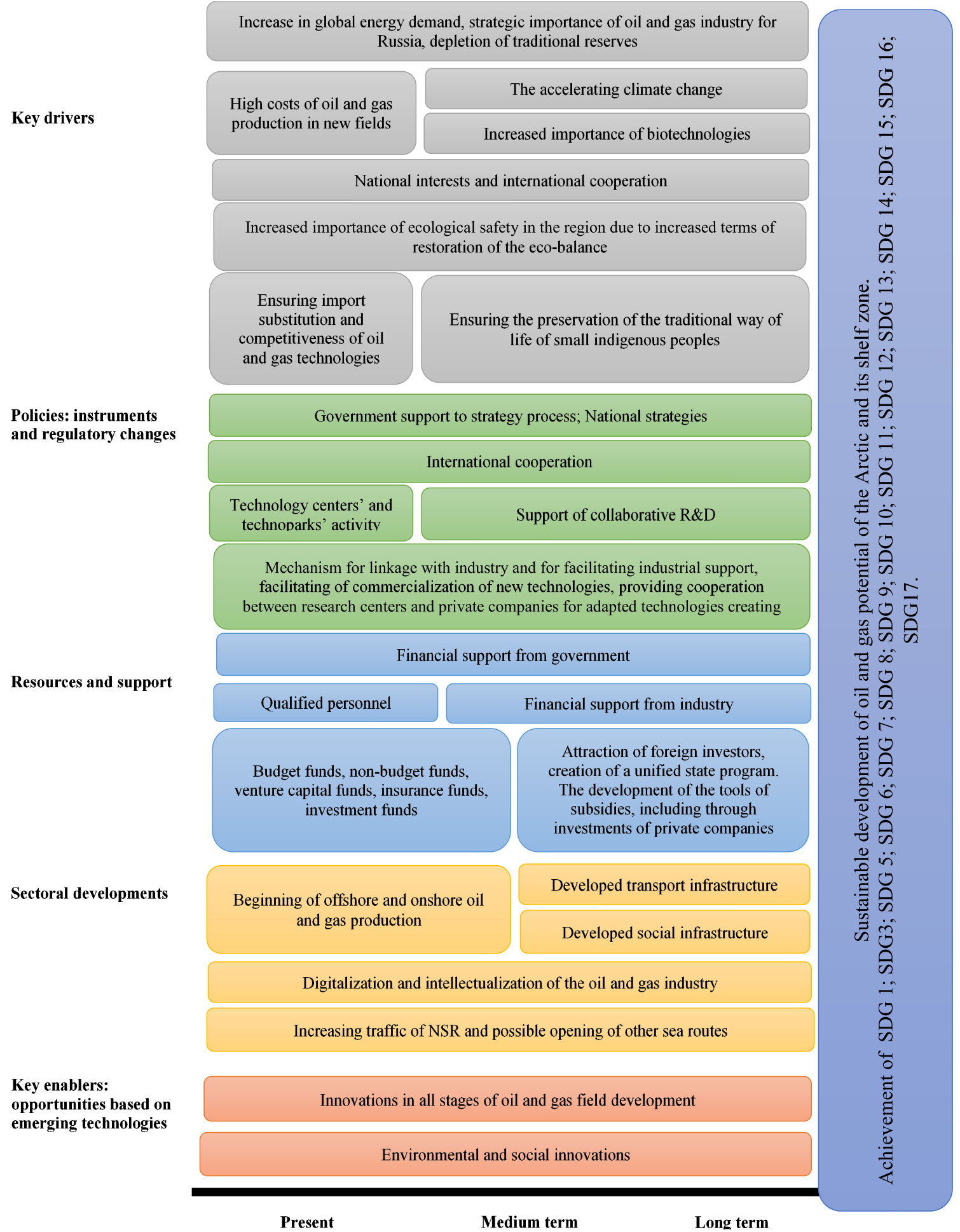

Figure 5. Innovation policy roadmap for sustainable development of oil and gas potential of the Arctic and its shelf zone.

The resources and support section provides information on which resources are needed to facilitate the process of innovations' implementation, and their movement from laboratories or universities to the market.

Sectoral development describes economic, industrial, environmental and social activities in the Arctic that could influence innovation activity in both sides-to promote or to impede it. The beginning of offshore and onshore oil and gas production as well as the digitalization and intellectualization 
of the oil and gas industry are the main sectoral characteristics that need innovation activity. In the medium term and long term, this could be supported by developed infrastructure, but at present this issue remains unsolved.

Key enablers provide existing or projected innovation technologies that support the innovation process for the sustainable development of oil and gas potential in the Arctic and support SDGs. We provide innovation technologies on all stages of the oil and gas field's development, and pay attention to environmental and social innovations.

IPRM brought together actors, processes and drivers of innovation activity in the development of oil and gas resources of the Arctic and its territories. It is seen that drivers provide challenges for innovation that require the support of sectoral development trends and that are impossible to implement without structured policy and different kinds of support from the state and companies.

In our research, we investigated the role of innovation for sustainability in the development of oil and gas potential of Arctic and its shelf zone. Thus, we studied how innovation leads to sustainability according to the SDGs. We tracked the role of existing and projected technologically innovative decisions on different stages of the exploration and exploitation process in sustainable development of the Russian Arctic zone. We highlighted the following stages: prospecting and exploration of hydrocarbon deposits; drilling oil and gas wells; development of hydrocarbon deposits; and transportation and storage of hydrocarbons, and the logistics and sales of products of their processing. We also emphasized environmental and social innovations.

We present existing and projected innovative technologies and solutions for development of resources in the Arctic and its offshore territories and substantiate their role in providing sustainability according to the adopted SDGs concept. The results are presented in Table 2.

As the table shows, specific innovative technologies contribute now or could contribute in the future to the achievement of sustainable development goals that in its turn provides sustainable development of oil and gas potential of the Russian Arctic and its shelf territories.

Sustainable development of offshore oil and gas resources is impossible without innovations in all stages of the process. Innovative technologies in exploration could lead to sustainability in the environmental, social and economic aspects. Russian companies are already implementing some innovations in the Arctic. For example, Gazprom Neft, during the development of offshore oil and gas fields, uses ice-resistant platforms on which drilling and production wells are placed, as well as a system for the remote control of equipment at the mouths of underwater wells. To organize its supply, the company has created a unique logistics scheme for the year-round transportation of hydrocarbons. Its key elements are the Prirazlomnaya oil production platform, the Arctic Gate terminal, a reinforced ice-class tanker fleet, its own and engaged icebreakers, and a roadside transshipment complex [53]. The world's first digital management system for Arctic logistics, "Kapitan", created by Gazprom Neft specialists, ensures the efficiency and safety of operations.

Therefore, the main findings of the research are the following:

(1) Sustainable development of oil and gas in the Arctic zone (especially the shelf) is a very urgent industrial and research issue due to the strategic importance of Arctic reserves, environmental and social challenges on the one hand and the lack of a research basis for it on another;

(2) Sustainable development of oil and gas fields in the Arctic zone is impossible without an innovative approach and the implementation of innovation policy, which could be done using the IPRM method;

(3) Understanding the role of innovations in the sustainable development of oil and gas potential of the Arctic zone is possible due to the innovation policy roadmap as well as tracking the achievement of SDGs using innovations;

(4) The SDGs concept needs adaptation to the peculiarities of development of oil and gas potential of the Arctic;

(5) The combination of IPRM and the identified role of innovation provides the possibility to distribute resources or other types of support on urgent issues, projects, spheres or territories. 
Table 2. Role of innovations in sustainable development of oil and gas potential of the Russian Arctic and its shelf zone.

\begin{tabular}{|c|c|c|c|c|}
\hline Spheres & & The Main Tools of Innovative Changes & $\begin{array}{l}\text { Role for Sustainable Development of Russian Arctic oil and } \\
\text { Gas Potential }\end{array}$ & Provided SDGs \\
\hline $\begin{array}{l}\text { Prospecting and exploration of } \\
\text { hydrocarbon deposits }\end{array}$ & (b) & $\begin{array}{l}\text { New technologies of seismic exploration (taking into account opportunities } \\
\text { of digital technologies): } \\
\text { - Basin modeling of hydrocarbon systems, forecasting promising zones } \\
\text { for hydrocarbon prospecting, assessment of geological and } \\
\text { geophysical risks; } \\
\text { 4D seismic monitoring for hydrocarbon deposits' prospecting, } \\
\text { clarifying the hydrodynamic model of hydrocarbon deposits, including } \\
\text { aquatically using "streamer cable", bottom fiber optic systems; } \\
\text { - Under-ice seismic exploration for hydrocarbon deposits' prospecting in } \\
\text { the Arctic regions in conditions when it is impossible or economically } \\
\text { unviable to carry out seismic exploration from land or from } \\
\text { geophysical vessels; } \\
\text { Pilotless aerial vehicle for carrying out aero-geophysical research; } \\
\text { Digital modeling of the pore space structure of reservoir layers and caprocks } \\
\text { of hydrocarbon deposits. } \\
\text { Technologies for studying and efficient operation of } \\
\text { unconventional reservoirs. }\end{array}$ & $\begin{array}{l}\text { Obtaining reliable information about the deep structure } \\
\text { of the subsoil, the structure of reservoir layers and } \\
\text { caprocks of oil and gas layers that provide higher } \\
\text { precision of the data for further extraction as well as for } \\
\text { planning future projects; } \\
\text { Providing possibilities for further development of } \\
\text { hard-to-recover resources and for more efficient use of } \\
\text { natural resources; } \\
\text { - Supplying oil and gas companies, the Russian Federation } \\
\text { and its regions with hydrocarbon resources. }\end{array}$ & $\begin{array}{l}\text { SDG1 } \\
\text { SDG7 } \\
\text { SDG8 } \\
\text { SDG9 } \\
\text { SDG12 } \\
\text { SDG15 }\end{array}$ \\
\hline Drilling oil and gas wells & $\begin{array}{l}\text { (a) } \\
\text { (b) } \\
\text { (c) }\end{array}$ & $\begin{array}{l}\text { Construction of multi-hole and directional wells; } \\
\text { High-strength drill bits; } \\
\text { Robotic drilling ships and platforms of a new generation, including those } \\
\text { for work in the Arctic: geolocation technology; icebreaker assistance or } \\
\text { icebreaking performance; drilling in deep water conditions; } \\
\text { Blowout-preventing drilling equipment, preventers in conditions of } \\
\text { abnormally high and abnormally low reservoir pressures and at great } \\
\text { depths in the World Ocean, including for work in the Arctic; } \\
\text { Energy efficient top drive drilling systems to increase the rate of drilling, } \\
\text { and to drill structurally difficult wells and improve safety while drilling. }\end{array}$ & $\begin{array}{l}\text { Involvement of multilayer hydrocarbon fields in effective } \\
\text { development, as well as reservoir layers at great depths } \\
\text { or in difficult geological conditions that provide } \\
\text { extraction of hydrocarbons in condition of scarcity of } \\
\text { existing resources; } \\
\text { - Reducing the cost of drilling prospecting and exploration } \\
\text { wells, as well as multi-hole and directional wells during } \\
\text { the operation of reservoir layers in hydrocarbon fields. }\end{array}$ & $\begin{array}{l}\text { SDG1 } \\
\text { SDG3 } \\
\text { SDG6 } \\
\text { SDG7 } \\
\text { SDG8 } \\
\text { SDG9 } \\
\text { SDG13 } \\
\text { SDG14 }\end{array}$ \\
\hline
\end{tabular}


Table 2. Cont

\begin{tabular}{|c|c|c|c|c|}
\hline Spheres & & The Main Tools of Innovative Changes & $\begin{array}{l}\text { Role for Sustainable Development of Russian Arctic oil and } \\
\text { Gas Potential }\end{array}$ & Provided SDGs \\
\hline Development of hydrocarbon deposits & $\begin{array}{l}\text { (a) } \\
\text { (b) }\end{array}$ & $\begin{array}{l}\text { Digital modeling of hydrocarbon fields with predetermined technical and } \\
\text { economic parameters: } \\
\text { Effective forecasting and use of methods to increase reservoir recovery at } \\
\text { various stages of hydrocarbon production; } \\
4 \mathrm{D} \text {, virtual and augmented reality technologies to support and make } \\
\text { management decisions; } \\
\text { - } \quad \text { Reengineering of "mature" hydrocarbon fields; } \\
\text { - Geological and technical measures to regulate the parameters of } \\
\text { hydrocarbon field development in accordance with the target values } \\
\text { for the hydrocarbon production volume; } \\
\text { Development technologies: fields of low-pressure gas (with low } \\
\text { pressure in the reservoir); deposits of "rich" gas (with a high content of } \\
\text { hydrocarbons from C3 and above); tight gas (shale); coalbed methane; } \\
\text { gas hydrates of permafrost and deep-water depressions of the } \\
\text { World Ocean; } \\
\text { Technologies and equipment for robotic subwater production complexes, } \\
\text { umanned technologies for mobile subwater and production platforms in } \\
\text { arctic conditions. }\end{array}$ & $\begin{array}{l}\text { - Rational use of energy from the subsoil, formation of the } \\
\text { ideology of the integrated development of hydrocarbon } \\
\text { fields and their infrastructure; } \\
\text { Reducing the cost of hydrocarbon production, increasing } \\
\text { the efficiency of field development; } \\
\text { - Increasing the effective oil recovery factor; } \\
\text { - Involvement of unconventional hydrocarbon deposits in } \\
\text { the development; } \\
\text { - Providing development offshore and marine resources. }\end{array}$ & $\begin{array}{l}\text { SDG1 } \\
\text { SDG6 } \\
\text { SDG7 } \\
\text { SDG8 } \\
\text { SDG9 } \\
\text { SDG12 } \\
\text { SDG14 } \\
\text { SDG15 } \\
\text { SDG17 }\end{array}$ \\
\hline $\begin{array}{l}\text { Transportation and storage of } \\
\text { hydrocarbons, logistics and sales of } \\
\text { products of their processing }\end{array}$ & (b) & $\begin{array}{l}\text { Highly efficient hydrocarbon pumping technologies: } \\
\text { - Energy efficient units (pumps, compressors, drives) with high } \\
\text { efficiency factor; } \\
\text { - Specialized steels, composite and additive materials, 3D printing of } \\
\text { finished products with high corrosion resistance and strength, for pipes } \\
\text { and technological equipment for hydrocarbon transportation } \\
\text { (including high pressure) and storage; } \\
\text { - Autonomous power component, renewable and alternative energy } \\
\text { sources for remote processing facilities of main and infield pipelines; } \\
\text { Intra-pipes diagnostics of main pipelines: } \\
\text { - Devices for intra-pipes diagnostics with specified technical } \\
\text { characteristics that are superior to world analogues - with the } \\
\text { combination of X-ray and ultrasonic signals, and without the use } \\
\text { of consumables; } \\
\text { Decrease in the energy consumption of intra-pipes "intelligent pigs" } \\
\text { with a decrease in the spacing of sensors and an increase in the } \\
\text { frequency of the "clearance" of the pipe metal for detecting } \\
\text { longitudinal and transverse defects; } \\
\text { Monitoring and forecasting the development of defects, and the digital } \\
\text { interpretation of data after diagnostics using digital } \\
\text { transformation tools; }\end{array}$ & $\begin{array}{l}\text { - Formation of a new transport and logistics infrastructure } \\
\text { of the Far East, Eastern Siberia and the Arctic, taking into } \\
\text { account the geological conditions of hydrocarbon fields } \\
\text { and technical and economic analysis of possible ways of } \\
\text { transporting hydrocarbons to markets, including the } \\
\text { end consumer; } \\
\text { Creation of an environment of "technological trust" and } \\
\text { effective interaction with the consumer based on } \\
\text { multivariate forecasting and guaranteed satisfaction of } \\
\text { demand for energy resources; } \\
\text { Extension of the maintenance-free service life, } \\
\text { accident-free operation, maintainability of main pipelines } \\
\text { and hydrocarbon storage facilities; } \\
\text { Reducing the cost of pumping hydrocarbons } \\
\text { through pipelines; } \\
\text { Reduction in technological losses during transportation } \\
\text { and storage of hydrocarbons and products of } \\
\text { their processing; } \\
\text { Development of private bunkering, coastal and tanker } \\
\text { fleets, including icebreaker vessels, and the } \\
\text { necessary infrastructure. }\end{array}$ & $\begin{array}{l}\text { SDG1 } \\
\text { SDG3 } \\
\text { SDG6 } \\
\text { SDG7 } \\
\text { SDG8 } \\
\text { SDG9 } \\
\text { SDG11 } \\
\text { SDG12 } \\
\text { SDG17 }\end{array}$ \\
\hline
\end{tabular}


Table 2. Cont

\begin{tabular}{|c|c|c|c|c|}
\hline Spheres & & The Main Tools of Innovative Changes & $\begin{array}{l}\text { Role for Sustainable Development of Russian Arctic oil and } \\
\text { Gas Potential }\end{array}$ & Provided SDGs \\
\hline & $\begin{array}{l}\text { (e) } \\
\text { (f) }\end{array}$ & $\begin{array}{l}\text { Technologies for protection from deposition in the main oil pipelines (from } \\
\text { paraffins), and in gas pipelines (from hydrates); development of } \\
\text { technologies for pumping gas in a two-phase or hydrated state; } \\
\text { Technologies and equipment for recovery of vapors of liquid hydrocarbons } \\
\text { during their storage, loading onto tankers, railway operations, and small } \\
\text { and medium-sized wholesale; } \\
\text { "Intelligent" devices for remote monitoring of transport infrastructure } \\
\text { objects to control the stress-strain state (especially in hard-to-reach areas, for } \\
\text { example, underwater, or in places of dangerous geological processes), } \\
\text { outflows and prevention of unauthorized impact (space technologies, } \\
\text { fiber-optic sensors, flying drones, etc.); } \\
\text { New technologies of welding production (especially for composite } \\
\text { materials), quality control of welded joints. }\end{array}$ & & \\
\hline Environmental innovations & (c) & $\begin{array}{l}\text { Non-explosive signal sources in seismic exploration; } \\
\text { During drilling and hydraulic fracturing: } \\
\text { - Underground utilization of drilling materials during the construction, } \\
\text { operation and repair of oil and gas wells; } \\
\text { - Closed systems for water treatment used to increase the recovery } \\
\text { of layers; } \\
\text { Environmentally friendly chemistry - drilling fluids, biodegradable } \\
\text { gels, inert materials for proppants; } \\
\text { Use of associated petroleum gas for own needs: } \\
\text { - Energy and heat generation; } \\
\text { - Production of aromatic hydrocarbons; } \\
\text { - Low-tonnage liquefied natural gas and compressed natural } \\
\text { gas facilities; } \\
\text { Nano-, composite and 3D materials, filter elements at all stages of } \\
\text { production, processing, logistics of oil, oil products, gas; } \\
\text { Biotechnology: } \\
\text { - Breeding of aquatic organisms (molluscs, scallops, sponges, fish) } \\
\text { offshore to recreate biodiversity, purification and monitoring of water } \\
\text { and bottom soil pollution with oil and oil products; } \\
\text { Sorbents and dispersants for the reclamation of land contaminated } \\
\text { with oil and oil products, oil and oil product spills on land and sea, } \\
\text { water and ice sludge purification in the Arctic regions; } \\
\text { To increase the layer recovery with the introduction of various bacteria } \\
\text { or their formation in the layer itself; }\end{array}$ & $\begin{array}{l}\text { Formation of the image of energy companies as } \\
\text { environmentally and socially responsible, providing } \\
\text { measures to prevent man-made harm in all segments of } \\
\text { oil and gas business, guaranteeing safety for life and } \\
\text { health of citizens, and environment; } \\
\text { The use of renewable and alternative energy sources in all } \\
\text { segments of oil and gas business to meet their own need } \\
\text { for energy resources (including the introduction of the } \\
\text { paradigm "oil and gas business is not a competitor, but a } \\
\text { partner of renewable energy sources"), reducing the } \\
\text { energy intensity of technological processes, reducing } \\
\text { costs and increasing economic performance; } \\
\text { Elimination of anthropogenic impact, implementation of } \\
\text { zero discharge technologies at oil and gas business } \\
\text { facilities in natural areas with a special status, seas } \\
\text { and oceans; } \\
\text { Development, implementation and independent control } \\
\text { of transparent generally accepted methods for assessing } \\
\text { anthropogenic and technogenic impact on } \\
\text { the environment. }\end{array}$ & $\begin{array}{l}\text { SDG3 } \\
\text { SDG6 } \\
\text { SDG7 } \\
\text { SDG9 } \\
\text { SDG11 } \\
\text { SDG12 } \\
\text { SDG13 } \\
\text { SDG14 } \\
\text { SDG15 } \\
\text { SDG17 }\end{array}$ \\
\hline
\end{tabular}


Table 2. Cont

\begin{tabular}{|c|c|c|c|c|}
\hline Spheres & & The Main Tools of Innovative Changes & $\begin{array}{l}\text { Role for Sustainable Development of Russian Arctic oil and } \\
\text { Gas Potential }\end{array}$ & Provided SDGs \\
\hline & (g) & $\begin{array}{l}\text { Technologies for the use of renewable energy sources (sun, wind, water) for } \\
\text { generating energy for own needs and at remote technological facilities, } \\
\text { carbon dioxide utilization processes, new energy distribution networks GTL } \\
\text { (gas-to-liquid), CTL (coal-to-liquid), Power-to-Gas and Gas-to-Power. } \\
\text { Infrared technology for the early discovery of spills, both underwater and on } \\
\text { the ocean surface, including infrared technology on a helicopter, an aircraft, } \\
\text { and on a preparedness vessel that was optimized to deal with cold weather }\end{array}$ & & \\
\hline Social innovations & $\begin{array}{l}\text { (a) } \\
\text { (b) } \\
\text { (c) } \\
\text { (d) } \\
\text { (e) }\end{array}$ & $\begin{array}{l}\text { Multi-stakeholder initiatives (MSI) with different aims, directions and } \\
\text { organizational designs; } \\
\text { Local forums for community development and capacity building; } \\
\text { Creative approaches to service provision; } \\
\text { Providing community spaces and activities; } \\
\text { Creating of the social movement such as the Association of indigenous } \\
\text { peoples of the North, Siberia and the Far East-the indigenous peoples of } \\
\text { the Arctic zone of the Russian Federation; } \\
\text { Advanced practices of regional international cooperation in the Arctic with } \\
\text { effective improvement of public administration at the level of local } \\
\text { self-government bodies (municipalities). }\end{array}$ & $\begin{array}{l}\text { - Protection of interests of indigenous people for providing } \\
\text { social sustainability; } \\
\text { Creation of social infrastructure both for native habitants } \\
\text { and for personnel; } \\
\text { Encouraging cooperation on different levels on issue of } \\
\text { social infrastructure development in the Arctic and } \\
\text { its shelf. }\end{array}$ & $\begin{array}{l}\text { SDG3 } \\
\text { SDG8 } \\
\text { SDG9 } \\
\text { SDG11 } \\
\text { SDG16 } \\
\text { SDG17 }\end{array}$ \\
\hline
\end{tabular}

Source: authors' own compilation using [37,50-52]. 
The results of the paper do not contradict previous studies [31-41] that underline the importance of innovation for resource-based industries and the strategic importance of the Arctic for Russia, and substantiate the necessity of sustainable development of its resources, but supplement them and contribute to research literature by providing the possibility to track the contribution of innovations to sustainable development through achieving SDGs. As for practical implementation, the results of the research could be used by government policy makers, by oil and gas companies during strategy formation, as well as by state and private R\&D companies.

The main assumptions of the research are the following: in the research we concentrated on Arctic territories of the Russian Federation and considered the peculiarities of Russian oil and gas potential, so the results for other countries could be interpreted in accordance with its features and characteristics; we did not consider specific indicators or quantitative measures of SDGs' achievement; we used open information sources.

As for future research directions, we could focus on innovative activity in different Arctic regions as well as providing an innovation policy roadmap not only for Russia, but also for all actors in the Arctic territory.

\section{Conclusions}

The Arctic region of Russia, including its shelf, is one of the most attractive and promising territories in terms of hydrocarbon production potential. The development of the Arctic is a high-tech and innovative process that determines the innovative development of a number of industries and territories.

Currently, there are more than 10 states operating on the shelf that already have technologies for the exploration and production of hydrocarbons. Therefore, effective development of the shelf by Russia is necessary in order not to increase the technological gap and to promote the sustainable development of offshore resources on the Arctic shelf aimed at economic profit, ecological sustainability and social responsibility. An innovative approach needs to be implemented in order to achieve this. According that background and the purpose of the research, the following results were obtained:

(1) Substantiation of strategic importance of sustainable development of Russian Arctic offshore oil and resources due to its great potential on the one hand and depletion of existing fields and scarcity of resources on the other.

(2) Identification of the main challenges that justify the necessity of an innovation approach for the sustainable development of Russian Arctic oil and gas potential, which is supported by national interests in this sphere.

(3) Adaptation of the SDGs concept to the issue of sustainable development of oil and gas potential of the Arctic and its shelf and the provision of a list of SDGs that are involved in this process and provide sustainability in economic, social and environmental aspects.

(4) Innovation policy roadmap for the sustainable development of the oil and gas potential of the Arctic and its shelf zone that presents actors involved in the process and facilitates the creation of a common vision for the basis of innovation policy as well as providing analysis of social, environmental, industrial and other aspects in policy practice that arise from technological development.

(5) Determining the role of innovation for the achievement of SDGs and for the sustainable development of the oil and gas potential of the Arctic and its shelf zone using IPRM together with the adopted SDGs concept.

Understanding the aforementioned role makes it possible to manage the innovation process in the Arctic resources' development depending on what goals and needs are extremely important or what problems need to be solved in the near future. For an effective innovation, development and implementation process, it is important to use the scientific potential of the Russian Federation with the involvement of leading foreign designers, acquire innovation technologies and production 
licenses, and involve leading foreign companies as subcontractors or on a joint basis. It is necessary to accumulate the organizational, technological and financial potential of the state and leading Russian oil and gas companies to coordinate and develop new technologies and designs, as well as to implement the program of exploration and development of mineral resources on the Arctic continental shelf, which will provide sustainable development for the region.

Author Contributions: Conceptualization, D.D.; methodology D.D. and N.R.; formal analysis, N.R.; resources D.D. and N.R.; writing - original draft preparation, D.D. All authors have read and agreed to the published version of the manuscript.

Funding: The research was carried out with the financial support of the grant by the President of the Russian Federation for the state support of leading scientific schools of the Russian Federation, the number of the project NSh-2692.2020.5 "Modelling of ecological-balanced and economically sustainable development of hydrocarbon resources of the Arctic".

Conflicts of Interest: The authors declare no conflict of interest. The funders had no role in the design of the study; in the collection, analyses, or interpretation of data; in the writing of the manuscript, or in the decision to publish the results.

\section{References}

1. Gritsenko, D.; Efimova, E. Is there Arctic resource curse? Evidence from the Russian Arctic regions. Resour. Policy 2020, 65. [CrossRef]

2. Alekseev, G.V.; Antipov, S.K.; Afonichkin, A.I.; Afonichkina, E.A.; Baburov, S.V.; Balashova, E.S.; Bondareva, N.N.; Borisov, V.N.; Vylegzhanina, A.O.; Goryachevskaya, E.S.; et al. The Arctic Space of Russia in the XXI Century: Development Factors, Management; Ivanter, V.V., Ed.; LLC Publishing House: St. Petersburg, Russia, 2016; pp. 630-655, ISBN 9785990233959.

3. Zuev, A. Oil and gas klondike of the Arctic. FEC Russia 2018, 12. Available online: https://www.cdu.ru/tek_ russia/issue/2018/12/545/ (accessed on 20 August 2020).

4. Dmitrievskiy, A.N.; Eremin, N.A.; Shabalin, N.A.; Kondratyuk, A.T.; Eremin, A.N. State and prospects for the development of hydrocarbon resources of the Arctic shelf of Russia. Neftegaz.RU 2017, 1, 32-41.

5. Krasnopol'skiy, V.G. Oil spills in the Arctic. Problems and solutions. Neftegaz.RU 2019, 5, 104-106.

6. Ilinova, A.A.; Dmitrieva, D.M. The mechanism of innovative development of the Russian arctic zone. Int. J. Mech. Eng. Technol. 2018, 9, 1439-1451.

7. Cherepovitsyn, A.E.; Kraslavski, A. Research of the innovative potential of an oil and gas company at different stages of field development. J. Min. Inst. 2016, 222, 892-902. [CrossRef]

8. Decree of the President of the Russian Federation No. 164 of 5th March, 2020. On the Fundamentals of State Policy of the Russian Federation in the Arctic for the Period up to 2035. Available online: https://www.gov.spb.ru/gov/otrasl/arkt/documents/ (accessed on 24 July 2020).

9. The Project of Strategy for the Development of the Arctic up to 2035 is Submitted to the Government of the Russian Federation. Available online: https://minvr.gov.ru/press-center/news/24847/ (accessed on 18 August 2020).

10. Malinauskaite, L.; Cook, D.; Davíðsdóttir, B.; Ögmundardóttir, H.; Roman, J. Ecosystem services in the Arctic: A thematic review. Ecosyst. Serv. 2019, 36. [CrossRef]

11. Kuzma, E.; Padilha, L.S.; Sehnem, S.; Julkovski, D.J.; Roman, D.J. The relationship between innovation and sustainability: A meta-analytic study. J. Clean. Prod. 2020, 259, 120745. [CrossRef]

12. Adams, R.; Jeanrenaud, S.; Bessant, J.; Denyer, D.; Overy, P. Sustainability-oriented Innovation: A Systematic Review. Int. J. Manag. Rev. 2016, 18, 180-205. [CrossRef]

13. Freire, R.; Costa, E.; Alves, J.; Brito, C. A dialectic on innovation and sustainability. International. J. Innov. Sustain. Dev. 2019, 13, 246-258. [CrossRef]

14. Shrivastava, P.; Ivanaj, S.; Ivanaj, V. Strategic technological innovation for sustainable development. Int. J. Technol. Manag. 2016, 70, 76-107. [CrossRef]

15. Omri, A. Technological innovation and sustainable development: Does the stage of development matter? Environ. Impact Assess. Rev. 2020, 83, 106398. [CrossRef]

16. Barbieri, J.C.; de Vasconcelos, I.F.G.; Andreassi, T.; de Vasconcelos, F.C. Innovation and sustainability: New models and propositions. Rev. Adm. Empres. 2010, 50, 146-154. [CrossRef] 
17. Nill, J.; Kemp, R. Evolutionary approaches for sustainable innovation policies: From niche to paradigm? Res. Policy 2009, 38, 668-680. [CrossRef]

18. United Nations Department of Economic and Social Affairs. Available online: https://sdgs.un.org/goals (accessed on 15 July 2020).

19. Rosati, F.; Faria, L.G.D. Business contribution to the Sustainable Development Agenda: Organizational factors related to early adoption of SDG reporting. Corp. Soc. Responsib. Environ. Manag. 2019, 26, 588-597. [CrossRef]

20. Ike, M.; Donovan, J.D.; Topple, C.; Masli, E.K. The process of selecting and prioritising corporate sustainability issues: Insights for achieving the Sustainable Development Goals. J. Clean. Prod. 2019, 236, 117661. [CrossRef]

21. Hacking, T. The SDGs and the sustainability assessment of private-sector projects: Theoretical conceptualisation and comparison with current practice using the case study of the Asian Development Bank. Impact Assess. Proj. Apprais. 2019, 37, 2-16. [CrossRef]

22. Omer, M.A.B.; Noguchi, T. A conceptual framework for understanding the contribution of building materials in the achievement of Sustainable Development Goals (SDGs). Sustain. Cities Soc. 2020, 52, 101869. [CrossRef]

23. Mapping Mining to the Sustainable Development Goals: An Atlas. Available online: https://www.commdev. org/pdf/publications/P_Mapping_Mining_SDG.pdf (accessed on 5 August 2020).

24. Starke, L. Breaking New Ground: Mining, Minerals and Sustainable Development; Routledge: London, UK, 2016; ISBN 9781315541501. [CrossRef]

25. Endl, A.; Tost, M.; Hitch, M.; Moser, P.; Feiel, S. Europe's mining innovation trends and their contribution to the sustainable development goals: Blind spots and strong points. Resour. Policy 2019, 101440. [CrossRef]

26. Gorman, M.R.; Dzombak, D.A. A review of sustainable mining and resource management: Transitioning from the life cycle of the mine to the life cycle of the mineral. Resour. Conserv. Recycl. 2018, 137, 281-291. [CrossRef]

27. Calas, G. Mineral Resources and Sustainable Development. Elements 2017, 13, 301-306. [CrossRef]

28. Ucal, M.; Xydis, G. Multidirectional Relationship between Energy Resources, Climate Changes and Sustainable Development: Technoeconomic Analysis. Sustain. Cities Soc. 2020, 60, 102210. [CrossRef]

29. Dobra, J.; Dobra, M.; Ouedraogo, A. Does mineral development provide a basis for sustainable economic development? Resour. Policy 2018, 58, 71-76. [CrossRef]

30. Katysheva, E.; Tsvetkova, A. Economic and institutional problems of the Russian oil and gas complex digital transformation. In Proceedings of the International Multidisciplinary Scientific GeoConference Surveying Geology and Mining Ecology Management, Albena, Bulgaria, 30 June-6 July 2019; STEF92 Technology Ltd.: Sofia, Bulgaria, 2019; Volume 19, pp. 203-208. [CrossRef]

31. Stadler, C. Process innovation and integration in process-oriented settings: The case of the oil industry. J. Prod. Innov. Manag. 2011, 28, 44-62. [CrossRef]

32. Radnejad, A.B.; Vredenburg, H.; Woiceshyn, J. Meta-organizing for open innovation under environmental and social pressures in the oil industry. Technovation 2017, 66, 14-27. [CrossRef]

33. Radnejad, A.B.; Vredenburg, H. Collaborative competitors in a fast-changing technology environment: Open innovation in environmental technology development in the oil and gas industry. Int. J. Entrep. Innov. Manag. 2015, 19,77-98. [CrossRef]

34. Radnejad, A.B.; Osiyevskyy, O.; Vredenburg, H. Barriers to radical process innovation: A case of environmental technology in the oil industry. J. Strategy Manag. 2020, 13, 453-476. [CrossRef]

35. Andreassen, N. Arctic energy development in Russia-How "sustainability" can fit? Energy Res. Soc. Sci. 2016, 16, 78-88. [CrossRef]

36. Hintsala, H.; Niemelä, S.; Tervonen, P. Arctic potential-Could more structured view improve the understanding of Arctic business opportunities? Polar Sci. 2016, 10, 450-457. [CrossRef]

37. Knol, M.; Arbo, P. Oil spill response in the Arctic: Norwegian experiences and future perspectives. Marine Policy 2014, 50, 171-177. [CrossRef]

38. Carayannis, E.; Ilinova, A.; Chanysheva, A. Russian Arctic Offshore Oil and Gas Projects: Methodological Framework for Evaluating Their Prospects. J. Knowl. Econ. 2019, 1-27. [CrossRef]

39. Harsem, Ø.; Eide, A.; Heen, K. Factors influencing future oil and gas prospects in the Arctic. Energy Policy 2011, 39, 8037-8045. [CrossRef]

40. Johannsdottir, L.; Cook, D. Systemic risk of maritime-related oil spills viewed from an Arctic and insurance perspective. Ocean Coastal Manag. 2019, 179. [CrossRef]

41. Carayannis, E.G.; Ilinova, A.A.; Cherepovitsyn, A.E. Sustainable Development of the Russian Arctic zone energy shelf: The Role of the Quintuple Innovation Helix Model. J. Knowl. Econ. June 2017, 8, 456-470. [CrossRef] 
42. Georghiou, L.; Keenan, M. Evaluation of National Foresight Activities: Assessing Rationale, Process and Impact. Technol. Forecast. Soc. Chang. 2006, 73, 761-777. [CrossRef]

43. Ahlqvist, T.; Valovirta, V.; Loikkanen, T. Innovation policy roadmapping as a systemic instrument for forward-looking policy design. Sci. Public Policy 2012, 39, 178-190. [CrossRef]

44. Rama Mohan, S. Strategy and design of Innovation Policy Road Mapping for a waste biorefinery. Bioresour. Technol. 2016, 215, 76-83. [CrossRef]

45. Cherepovitsyn, A.E.; Chvileva, T.A.; Romasheva, N.V. Prospects for the exploration of hydrocarbon deposits in the Arctic based on socio-economic evaluation. Int. J. Civ. Eng. Technol. 2018, 9, 938-948.

46. Kruk, M.; Semenov, A.; Cherepovitsyn, A.; Nikulina, A. Environmental and economic damage from the development of oil and gas fields in the Arctic shelf of the Russian Federation. Eur. Res. Stud. J. 2018, 21, 423-433.

47. Savard, C.; Nikulina, A.; Mécemmène, C.; Mokhova, E. The Electrification of Ships Using the Northern Sea Route: An Approach. J. Open Innov. Technol. Mark. Complex. 2020, 6, 13. [CrossRef]

48. Malaurie, J. Arctic Peoples in a Changing Environment: A Humanist's Vision. In Climate Change and Arctic Sustainable Development: Scientific, Social, Cultural and Educational Challenges; UNESCO: Paris, France, 2009; pp. 131-136, ISBN 9789231041396.

49. Abryutina, L. Indigenous Peoples of the Russian North: Social and Climatic Changes. In Climate Change and Arctic Sustainable Development: Scientific, Social, Cultural and Educational Challenges; UNESCO: Paris, France, 2009; pp. 181-190, ISBN 978-92-3-104139-6.

50. Sauer, P.C.; Hiete, M. Multi-Stakeholder Initiatives as Social Innovation for Governance and Practice: A Review of Responsible Mining Initiatives. Sustainability 2020, 12, 236. [CrossRef]

51. Smorchkova, V.I.; Kharlamp'eva, N.D. Social innovations in Arctic municipalities as a factor of sustainable development. Arctic XXI Century Hum. Sci. 2015, 1, 30-39.

52. Martynov, V.G.; Golunov, N.N.; Makarova, E.D. Foresight of innovation. Changes in technologies and tools for management of innovations in the oil and gas complex. Neftegaz RU 2020, 6, 16-27.

53. Official Website of Gazprom Neft Company. Available online: https://www.gazprom-neft.ru (accessed on 20 August 2020).

Publisher's Note: MDPI stays neutral with regard to jurisdictional claims in published maps and institutional affiliations.

(C) 2020 by the authors. Licensee MDPI, Basel, Switzerland. This article is an open access article distributed under the terms and conditions of the Creative Commons Attribution (CC BY) license (http://creativecommons.org/licenses/by/4.0/). 